\title{
The relationship between femininity and sustainability reporting
}

Author's names:

María L. Gallén ${ }^{1}$

Carlos Peraita $^{2}$

${ }^{1}$ Department of Accounting, Faculty of Economics, University of Valencia, Valencia, Spain.

2 Department of Economic Analysis, Faculty of Economics, University of Valencia, Valencia, Spain.

Full address of the corresponding author:

Carlos Peraita

Facultad de Economía, Universitat de València, Av. de los Naranjos s/n. 46022 Valencia (SPAIN)

Telephone: (34) 963828259, Fax: (34) 963828249

Email: Carlos.Peraita@uv.es

Sponsors and grant number:

C. Peraita gratefully acknowledges the financial support from the Spanish Ministry of Economy and Competitiveness under the research project ECO2015-70632-R.

\begin{abstract}
Most research on corporate social responsibility (CSR) disclosure and the stakeholder engagement with sustainable development has focused on the internal factors of corporations, leaving aside the characteristics of the institutional, cultural and economic context of the country where corporations operate. The purpose of this study is to investigate the influence of femininity in the disclosure of sustainability information based on the Global Reporting Initiative (GRI) guidelines at a developed country context. We use three measures of the CSR information disclosure by country: the GRI reports per million of inhabitants, the GRI reports application level, and the percentage of GRI reports with external assurance. The results of this study show that countries with higher femininity orientation provide higher quantity of sustainability reports, but do not provide higher quality of sustainability reports.
\end{abstract}

Keywords: femininity; gender; CSR; GRI; sustainability; stakeholder engagement. 


\section{Introduction}

Why are there differences in the quantity and the quality of sustainability reports issued in countries like Australia and United States? Both countries have a similar gross domestic product per capita (in 2015, Australia had 56,327 current US\$ and United States had 55,836 current US\$) and both are countries with a common-law tradition. The Global Reporting Initiative (GRI) reports released by organizations in the United States double the GRI reports in Australia, but the population in United States is 13.5 times superior to the one in Australia. In addition, the application level GRI reports and the percentage of assurance are quite lower in United States than in Australia.

Most corporate social responsibility (CSR) studies analyze the internal corporate characteristics, and they have identified that the size, the type of industry, the financial performance, and the composition of the board of directors, among others, are factors that explain the differences in sustainability reporting. However, the political, economic and cultural context of the countries where organizations reside also affects the disclosure of sustainability information (Adams, 2002), and yet little research has explored the differences in CSR disclosures among countries.

The purpose of our study is to extend existing literature on CSR with the analysis of the external factors to the organization incorporating one dimension of the national culture, the femininity-masculinity, controlling by the size in terms of population, by the economic conditions, and by the legal system of the country. To compare the information of sustainability among countries we have used the GRI reports because is the generally accepted standard framework in sustainability information (Hedberg \& von Malmborg, 2003).

We structure the remainder of the paper as follows. In the next section, we present a review of the literature and develop our hypotheses. Then, we present the research design and the results. In the last section, we discuss our conclusions and implications.

\section{Literature Review and Hypotheses}

The sociological new institutionalism considers that institutions are elements that explain the organizations' behavior and structure. Although the concept of institution has been defined in diverse ways, according to North (1990) the institutions are the formal rules (laws and governmental regulations) and informal constraints in a society (culture). This paradigm explains the changes in the organizations primarily as a process of social legitimacy based on the concept of institutional isomorphism, and the three mechanisms through which it occurs: coercive, mimetic and normative. In this context, DiMaggio \& Powel (1983) argued that the external actors make their organizations increasingly similar in structure and behaviour. This is why organizations located in the same environment will be most homogeneous in their characteristics.

The institutional theory allowed us to understand the differences in the CSR strategies at macro-level. The institutions vary across countries and can enable and constrain the degree to which stakeholders influence in the CSR practices (Campbell, 2006). In short, economic conditions affect corporate CSR, but institutional conditions are also determinant (Campbell, 2007).

The cultural system is a key feature of the national institutional frameworks (Matten \& Moon, 2008). Although there are various studies that offer measurements of national culture (e.g. House et al., 2004), the cultural dimensions of Hofstede (1980) are the most used by the researchers. One of these dimensions is the masculinity-femininity of a 
society, which is the degree to which masculine values, such as the ambition, power and materialism prevail over feminine values, such as the quality of life and emphasis on personal relationships.

This paper focuses only in the masculinity/femininity dimension among other aspects of personality and culture for two reasons. On the one hand, because this cultural dimension has been one of the most important topics in previous research on CSR at the corporation level and our paper aims to expand the analysis at the country level. On the other hand, we are convinced that gender diversity is the cultural variable that has one of the greatest effects on the dissemination of sustainability because political institutions can influence this cultural dimension and, therefore, support greater female participation in all activities of the society.

The literature seems to confirm that men and women are different in their personality and social behaviors. Brody (1985) indicates that the differences between men and women may be a function of different socialization processes, because there are gender differences in several emotional areas. Hyde (2014) conducted a meta-analysis and concluded that males and females are similar on most, but not all, psychological variables. There are exceptions in dimensions such as agreeableness, extraversion, interests in things versus people, and physical aggression. The meta-analysis of Konrad et al. (2000) indicates that men considered earnings and responsibility to be more important, whereas women considered prestige, challenges and job security more important.

However, the studies that examine the relationship between gender and ethical attitudes are not conclusive. Ruegger \& King (1992) find that females are more ethical than males in their perception of business ethical situations. Ameen et al. (1996) show that women tend to be more sensitive and less tolerant of unethical behaviors than men. In contrast, Sikula \& Costa (1994) report that women and men are ethically equivalent, women only differ on non-ethical values. Marques \& Azevedo-Pereira (2009) suggest that men are stricter than women when making ethical judgments. Wang \& Calvano (2015) indicate that women are more inclined to act ethically than men when they have not received business ethics education, but males who have had business ethics instruction are more likely to respond ethically.

The relationship of CSR with the femininity has been investigated mainly using factors such as the gender composition of the board of directors and the cultural masculinity's dimension. About the effect of gender composition of the board in CSR, Boulouta (2013) finds that the proportion of women in the board of directors has a positive relationship with CSR, but the significance depends on the social performance metric used. Landry et al. (2014) find that the corporations listed on one or more of 'best' lists over CSR had a higher average representation of women on their boards. Setó-Pamies (2015), using the global ranking of the 100 most sustainable corporations, also confirms that the presence of women on the board has a positive influence in CSR. Kassinis et al. (2016) show companies that have more women on its boards of directors are more environmentally conscious. Similarly, Fernandez-Feijoo et al. (2014) find that boards with three or more women are determinants for CSR disclosure. However, Amran et al. (2014) suggest that the gender proportion of a board of directors is not associated significantly with the quality of sustainability reports in the Asia-Pacific.

Williams (1999) analyses the relationship between cultural dimension of masculinity and sustainability information and finds that firms operating in countries with more masculinity provide little quantity of environmental and social information. Van der Laan Smith et al. (2005) find that companies from Norway and Denmark -considered by Hofstede (1980) as two of the countries with most femininity- have a higher quantity and quality of corporate social disclosures than companies from United States. Similarly, Orij 
(2010) shows that companies in countries with higher masculinity have lower levels of corporate social disclosures. More recently, the study of Garcia-Sanchez et al. (2016) shows a negative regression coefficient between the country's masculinity and the implementation GRI guidelines in the companies.

The effect of the masculinity also has been analysed using other measures of CSR that are not the sustainability disclosure of information. Ringov \& Zollo (2007) find that masculinity has a negative influence on the companies' social and environmental performances. Scholtens \& Sievänen (2013) investigate the differences in the socially responsible investing (SRI) in Nordic countries and their study shows that Norway and Sweden, that have more femininity than Finland and Denmark, are both SRI pioneers. Hur et al. (2016) and Jones et al. (2017) find that female consumers have higher perceptions toward CSR than male consumers. Thanetsunthorn (2015) shows that masculinity has a significantly negative association with CSR performance on employee and community dimensions, but there is no significant relationship with the environmental dimension. In addition to all this empirical evidence, Ho et al. (2012) find a positive relationship between masculinity and CSR that is inconsistent with the prediction they had initially established, although the authors of the study argue that this result could be caused by the endogeneity of the cultural dimension and the control variables used in their study ( $\mathrm{p}$. 431).

In summary, the literature is quite consistent when establishing a negative relationship between CSR and the masculinity in different countries, but it is important and necessary to note that CSR measures used in the studies are different from each other and that the comparisons between countries are set at the company level.

In our study, the "countries with higher femininity orientation" are the countries with higher level of equality between women and men. In accordance with the revised literature, in our analysis of the level of gender equality in a country we have considered its political, economic and cultural dimensions. The political area is measured with the presence of women in national parliaments. The economic dimension is measured with the labour market participation of women. The femininity culture in the country is valued with the Hofstede's dimension.

Before formulating our hypotheses some formal definitions are necessary. In this paper we define the "quantity of sustainability reports" in a country as the number of sustainability reports issued by the organizations (companies, non- profit services, public agency and universities) according to GRI guidelines and standardized by the number of inhabitants of the country.

Similarly, our paper defines the "quality of sustainability reports" in a country by the level of disclosure of GRI reports and by the proportion of guarantees in GRI reports. We assume that the higher levels of application of the GRI guidelines are measuring the greater transparency and the quality of information. In addition, we argue that voluntary adoption of the external assurance of reports is a measure of the quality of GRI reports because this practice increases their credibility. The GRI application level as measure of CSR disclosure has been used in some recent studies (Ortas et al., 2015; Alberici \& Querci, 2016; Martínez-Ferrero et al., 2016; García-Sánchez \& Martínez-Ferrero, 2017). The assurance of GRI reports as a measure of quality of voluntary disclosure has been used by Moroney et al. (2012) and Herda et al. (2014).

For all these reasons, our hypotheses are the followings:

Hypothesis 1. Countries with higher femininity orientation will provide higher quantity of sustainability reports. 
Hypothesis 2. Countries with higher femininity orientation will provide higher quality of sustainability reports.

\section{Research Design}

\section{Sample and Data Sources}

The sample used in this study includes 7,740 organizations that have released sustainability reports applying GRI (G3 and G3.1) guidelines in the period 2007-2012 in 30 countries of the OECD. In these guidelines, the quality of the reporting is presented on three application levels $(\mathrm{C}, \mathrm{B}$, and $\mathrm{A})$. The reporting criteria at each level reflects a measure of the extent of application or coverage of the GRI reporting framework. The level $\mathrm{C}$ represents the small disclosures items and the level $\mathrm{A}$ represents the highest disclosures. Additionally, a "plus" $(+)$ is available at each level $(\mathrm{C}+, \mathrm{B}+, \mathrm{A}+)$ if external assurance was used in the report.

We have excluded GRI G4 guidelines, adopted in 2013, because they use another application level and change the measure of the quality of the sustainability information. The G3 guidelines were released in 2006, but it is in 2007 when it was used in a greater proportion than G2 guidelines. Of the 35 countries of the OECD, we have eliminated five countries because they do not have at least one GRI report in every year over the period of study. Thus, the countries eliminated are Estonia, Iceland, Latvia, Slovak Republic and Slovenia. Table 1 and Table 2 describe the final sample used to conduct our study. We collected our GRI information from GRI database (https://database.globalreporting.org/) and the dates of population from the World Bank (https://data.worldbank.org/).

The Table 1 shows that United States (13.27\%), Spain (12.36\%), South Korea $(6.41 \%)$ and Australia (5.90\%) are the countries with the higher percentage of GRI reports of the total of the sample. However, when the number of reports are standardized by millions of inhabitants, the Table 1 shows that United States is in the position $24(0.55)$, Spain is in the position 8 (3.44), South Korea is in the position 17 (1.67), and Australia has the position 7 (3.47). Similarly, Sweden (7.58), Luxembourg (6.840), Switzerland (5.88) and Finland (5.675) are in the top positions in GRI reports per million inhabitants.

Table 1 also shows the application level and the percentage of assurance of GRI reports. The countries with higher disclosures levels are Spain (5.36), Ireland (5.33), Italy (5.06) and South Korea (4.49). The sample mean of application level of GRI reports is 3.65 points ( 7 points maximum). The countries with higher assurance of GRI reports are Ireland (71.11\%), Italy (61.24\%), Austria (60.94\%), and Czech Republic (58.33\%). The sample mean of assurance is $35.87 \%$. Japan and United States are, together with Turkey, the three countries with less assurance of GRI reports, and they are situated in the lower positions in the application level.

Table 2 presents the distribution of GRI reports by country and industry. Although the database of GRI reports included 38 industries, we used the Global Industry Classification Standard codes (two digits) plus an additional one for the aggregation of three GRI industries, 'Nonprofit Services, Public Agencies and Universities'. Over all OECD countries, the two economic sectors with more GRI proportion of reports are Financials $(15.5 \%)$ and Materials (13.3\%). The 'Non Profit Services, Public Agencies and Universities' category represents $6.2 \%$ of the GRI reports, and it is an indicator of the sustainability reporting practices for non-business organizations. Finally, $8.6 \%$ of GRI reports has not declared the type of industry and it is classified in the 'Other' category. 


\section{Dependent Variables}

In our regression analysis, we used three dependent variables, one of them for the quantity of sustainability reports and the other two for the quality of sustainability reports. The first dependent variable, NumGRI, measure the G3 and G3.1 reports per million of inhabitants by country and year. The second dependent variable, LevelGRI, measure the application level of G3 and G3.1 reports by country and year. This variable is elaborated as follows: the G3 and G3.1 reports for each application level and country/year are divided by the total reports by country/year and the scale of Legendre and Coderre (2013) multiplies the results. The values of this scale are: level $A+=7$ points, level $A=6$ points, level $B+=5$ points, level $\mathrm{B}=4$ points, level $\mathrm{C}+=3$ points, level $\mathrm{C}=2$ points, and undeclared $=1$ point. Finally, the third dependent variable, AssurGRI, measures the percentage of G3 and G3.1 reports by country/year that have used external assurance.

\section{Independent and Control Variables}

The independent variable is the countries' femininity. To measure the femininity we use three alternatives: (a) SeatsFemale, as the proportion of seats held by women in national parliament (World Bank); (b) LaborFemale, as the female labour force participation rate (World Bank); and (c) Masculinity, which is obtained from Hofstede's cultural dimension (Hofstede, 1980; and https://geert-hofstede.com). In addition, all models include four control variables: the Gross Domestic Product per capita (GDPPC) in natural logarithms; Industry1; Industry2; and Legal. The definition of the last four variables is presented below and their incorporation in our regressions is justified.

The GDPPC is incorporated as a control variable to measure the effects of the economic conditions of a country, because higher levels of economic development could lead to higher levels of CSR activities and more sustainability reporting (Baughn et al., 2007; Li et al., 2010). The GDPPC data (current US\$) is obtained from the World Bank.

Literature demonstrates that the type of industry explains the quantity and the quality of the sustainability reports. In fact, there are industries with high environmental impacts, so called environmentally-sensitive industries, and industries have a high political visibility because they have greater proximity to consumers, investors or employees (FernandezFeijoo et al., 2012). Consequently, the companies of environmentally-sensitive industries disclose more CSR information and their reports are externally assured in more proportion than companies installed in other industries because they seek the acceptance of their activities from stakeholders (Brammer \& Pavelin, 2008; Kolk \& Perego, 2010; Moroney et al., 2012; Toppinen et al. 2012; Sierra et al., 2013; Alonso-Almeida et al., 2014). Thus, Industry 1 is a control variable that measures the percentage of GRI reports disclosed by the high-risk industries over the total GRI reports by country and year. For the classification as a high-risk industry, we used Legendre \& Coderre's criteria (2013): petroleum, chemical, forest and paper, automobile, airline, oil, agriculture, liquor and tobacco, and media and communications.

In addition, we have incorporated Industry 2 as a control variable to measure the effect of financial services industries because the analysed period corresponds to the years of the global financial crisis. Over this period, the financial industry has been under public scrutiny and its companies have disclosed CSR reports as a strategy to legitimize their 
behavior towards society (Andrikopoulos et al., 2014; Lock \& Seele, 2015). This variable is defined as the percentage of GRI reports disclosed by the financial services industry over the total GRI reports by country and year.

The last control variable is Legal, a dichotomous variable that takes the value one for common-law countries (Australia, Canada, Ireland, Israel, New Zealand, United Kingdom and United States) and the value zero for civil-law countries. Thus, Simmet et al. (2009) and Kolk \& Perego (2010) found that companies domiciled in civil-law countries are more likely to have a sustainability reports assured. However, Herda et al. (2014) didn't find out any significant differences between civil-law and common-law countries in their probabilities of assuring the sustainability reports. The study of Garcia-Sánchez et al. (2015) also showed that companies located in civil-law countries produced more sustainability reports than those located in common-law countries.

\section{Results}

\section{Descriptive Statistics}

Table 3 provides descriptive statistics of the variables and correlations. NumGRI is significantly correlated with all independent variables, with the exception of Industry2, and the higher positive association is with SeatsFemale variable. The negative correlation of NumGRI with Industry1 is surprising. The LevelGRI variable is only positively correlated with Industry1 and Industry2. AssurGRI is not significantly correlated with Industry1, but shows a significant correlation with Industry2, and somewhat lower with GDPPC and SeatsFemale.

\section{Insert Table 3 here}

\section{Regression Results}

In order to test our hypotheses, we used a balanced panel data and we estimated all models for pooled ordinary least squares and for random effects. To check for multicollinearity, we have calculated the variance inflation factor (VIF) for all regressions, which is less than 2.2 for all independent variables. Thus, multicollinearity is not a problem in our panel data models. However, our models have a heteroscedasticity problem (determined from the Levene's test), and have an autocorrelation problem (verified with the Wooldridge's test). Therefore, in the presence of heteroscedasticity and autocorrelation we have estimated the models with feasible general least squares method (FGLS) and panel corrected standard errors (PCSE). Although there is literature suggesting that the estimations of PCSE's models are more accurate for finite samples (e.g. Beck \& Katz, 1995), the tables presented in this section include the results of the regressions FGLS and PCSE.

Table 4 reports the results of our estimations to contrast the hypothesis 1 . The three variables used to measure the femininity are statistically significant and with the expected sign. SeatsFemale and LaborFemale have a positive effect on NumGRI, and the coefficient of Masculinity shows a negative relation with NumGRI. The results also reveal that the effect of GDPPC on NumGRI is positive and significant in all models. The Legal variable has a negative effect on NumGRI in all models. This result supports the idea that civil-law countries provide more GRI reports per million inhabitants than common-law countries. The Industry1 variable presents negative coefficients that are statistically 
significant with all PCSE estimations, but only in one of the models estimated by FGLS. Additionally, the Industry 2 variable does not reach statistical significance in any of our estimated models.

Therefore, the results show that countries with higher femininity orientation provide higher quantity of GRI reports per million of inhabitants. The estimations have included the femininity variable in its three alternative dimensions (political, economic and cultural) and the results have confirmed the predictions for each of these dimension. Although our results confirm the positive effect of GDPPC on NumGRI, they do not confirm the expected positive effect of the type of industries (Industry1 and Industry2) on the number of GRI reports per million inhabitants. One possible explanation for this result is that our research has been carried out exclusively using different measures of variables at macro level (country level).

\title{
Insert Table 4 here
}

Table 5 and Table 6 show the results to contrast the hypothesis 2 . When the quality of the sustainability reports is measured by the application level of GRI reports (Table 5), we find that only the Industry1 and Industry 2 variables are significant and have a positive coefficient in the FGLS and PCSE models. The same results are obtained when the quality of the sustainability reports is measured by the percentage of GRI reports with external assurance (Table 6). Consequently, the results of our econometric models with panel data do not provide support for hypothesis 2 ; that is, the femininity of the countries does not affect the quality of GRI reports. The GDPPC and Legal variables are not significant in any of the estimations presented in Tables 5 and 6 . However, the two variables reflecting the type of industries (Industry1 and Industry2) present positive and significant effects on the quality of sustainability information. Therefore, the quality of GRI reports is directly related with the type of industry, and countries with a higher proportion of GRI reports submitted by high-risk industries and financial services industry have a higher application level of GRI reports that is also subject to assurance in a higher percentage. Finally, the results indicate that the femininity of the country, like its Gross Domestic Product per capita or the traditional dichotomy civil laws/common laws, has no significant influence on the quality of GRI reports.

\author{
Insert Table 5 here \\ Insert Table 6 here
}

\section{Sensitivity Analysis}

In order to test the sensitivity of our results, we have introduced the following modifications. On the one hand, we have deleted the GDPPC variable due to its high correlation with SeatsFemale and LaborFemale. The results obtained are as follows. In the models with NumGRI as a dependent variable, the regression coefficients of the three variables that measure the femininity are significant and present the expected sign, but the Legal variable only is significant in the econometric regressions when the femininity is measured through the LaborFemale variable. These changes in the statistical significance of the Legal variable suggests that its influence on NumGRI is conditioned by its interaction with the GDPPC variable. In addition, the sign of the coefficient of Industry1 continues to be negative, but is statistically significant in all estimated models. In the models with LevelGRI and AssurGRI as dependent variables, the results are identical: only the regression coefficients of Industry1 and Industry2 variables are significant. 
On the other hand, we have changed the variable that measures the legal system of the countries (Legal) by a new variable named 'Rule of Law', that is one of the Worldwide Governance Indicators developed by Kauffmann et al. (1999) and available at databank.worldbank.org/. The 'Rule of Law' has been used in CSR by Simnett et al. (2009) and Herda et al. (2014). After carrying out this substitution, the results obtained in the models with NumGRI as a dependent variable are maintained for SeatsFemale, LaborFemale and Masculinity variables. The 'Rule of Law' variable is significant with SeatsFemale and with LaborFemale, but not with masculinity variable. However, the GDPPC variable is only statistically significant in the FGLS model that incorporates the Masculinity variable. The changes in the significance of this GDPPC control variable can be explained by its high correlation with 'Rule of Law' (0.80). In fact, the correlation of the 'Rule of Law' is also high with LaborFemale (0.78) and with SeatsFemale (0.45). The VIF for 'Rule of Law' variable is between 3.15 and 4.21. In addition, the results are maintained in the models with LevelGRI and AssurGRI as dependent variables.

\section{Conclusions and Implications}

The objective of this research was to analyze the effect of femininity on the sustainability reporting in developed countries. According to institutional theory, we assume that organizations that operate in the same country are quite homogeneous in their behavior with stakeholders because they have the same cultural pressure. We have measured femininity with the political participation of women in national parliaments, the economic participation of women in labor force, and with the masculinity coefficients of Hofstede (1980).

The results show that there is a positive and very significant relationship between the femininity of a country and the quantity of sustainability reports, measured by the number of GRI reported per million inhabitants, and controlled for the gross domestic product per capita, the type of legal system, and the type of industry. However, the femininity of the country does not affect the quality of sustainability reports, measured by the application level of GRI reports and the external assurance of GRI reports. The quality of the sustainability disclosure seems to be exclusively related to the type of industry. Thus, the high-risk industries, with an environmentally high impact and high visibility such as media and communications, and the financial services industries are the ones that disclosure GRI reports with higher quality.

In addition, our study finds out that the relationship between femininity and CSR is not always positive because it depends on the CSR metric used. Therefore, our results cannot be compared with any previous study because we have used other measures for CSR and our work has been carried out at country level. However, the CSR measure used by Legendre \& Coderre (2013) has been also used in our study at the country level, and the results confirm the importance of the type of industry of OECD countries in their CSR reporting.

Managers and politicians could use the main results of our research as a strategic and planning tool to increase the sustainability reporting both at the company and country level. Economic development favours the disclosure of comparable sustainability information between countries, but other factors also have a very positive effect on these practices. The degree of femininity of the countries positively affects the demand for GRI reports. As a result, the social pressure on organizations to increase the quantity and quality of CSR reports will increase as countries also increase their femininity and reduce their gender differences. This implication is important, since the external factors analyzed 
do not seem to have a significant effect on the voluntary assurance of sustainability reports.

Our research has also some implications for sustainability reporting practice because it points out factors that influence the quantity and quality of non-financial information. Undoubtedly, economic development and increasing femininity in countries will affect the quantity of GRI reports, but these changes may be slow over time and may have a minor effect on the quality of this information. Consequently, political institutions can develop regulatory actions and adopt legislative changes that allow countries to accelerate and anticipate future demands for non-financial information. Institutional requirements appear to be a necessary tool to ensure a minimum level of disclosure of sustainability information as well as to ensure credibility through external assurance of GRI reports.

Finally, and following the results obtained, the measures that favour a greater female participation in the economy or in politics will cause increases in the voluntary information of sustainability; and vice versa, the changes towards a greater masculinity in politics or in the economy will have a negative effect. However, these measures favouring femininity of the countries do not imply that sustainability reports were issued with higher quality. The quality of sustainability reports at country level seems to depend on the potential political and social costs of their industries. Therefore, companies in industries with greater political visibility will disclose sustainability reports with greater quality because they seek their legitimation with stakeholders.

\section{Acknowledgements}

The authors would like to thank the Editor and two reviewers for their valuable comments and suggestions to improve the quality of the paper.

\section{References}

Alberici A, Querci F. 2016. The quality of disclosures on environmental policy: The profile of financial intermediaries. Corporate Social Responsibility and Environmental Management 23(5): 283-296. DOI: 10.1002/csr.1375

Alonso-Almeida M, Llach J, Marimon F. 2014. A closer look at the 'Global Reporting Initiative'sustainability reporting as a tool to implement environmental and social policies: A worldwide sector analysis. Corporate Social Responsibility and Environmental Management 21(6): 318-335. DOI: 10.1002/csr.1318

Ameen EC, Guffey DM, McMillan JJ. 1996. Gender differences in determining the ethical sensitivity of future accounting professionals. Journal of Business Ethics 15(5): 591-597. DOI: 10.1007/BF00381934

Amran A, Lee SP, Devi, SS. 2014. The influence of governance structure and strategic corporate social responsibility toward sustainability reporting quality. Business Strategy and the Environment 23(4): 217-235. DOI: 10.1002/bse.1767

Andrikopoulos A, Samitas A, Bekiaris M. 2014. Corporate social responsibility reporting in financial institutions: Evidence from Euronext. Research in International Business and Finance 32: 27-35. DOI: 10.1016/j.ribaf.2014.02.001

Baughn CC, Bodie NL, McIntosh, JC. 2007. Corporate social and environmental responsibility in Asian countries and other geographical regions. Corporate Social Responsibility and Environmental Management 14(4): 189-205. DOI: $10.1002 / \mathrm{csr} .160$ 
Beck N, Katz JN. 1995. What to do (and not to do) with times-series cross-section data in comparative politics. American Political Science Review 89(3): 634-647. DOI: $10.2307 / 2082979$

Boulouta I. 2013. Hidden connections: The link between board gender diversity and corporate social performance. Journal of Business Ethics 113(2): 185-197. DOI: 10.1007/s10551-012-1293-7

Brammer S, Pavelin S. 2008. Factors influencing the quality of corporate environmental disclosure. Business Strategy and the Environment 17(2): 120-136. DOI: 10.1002/bse.506

Brody LR. 1985. Gender differences in emotional development: A review of theories and research. Journal of Personality 53(2): 102-149. DOI: 10.1111/j.14676494.1985.tb00361.x

Campbell JL. 2006. Institutional Analysis and the Paradox of Corporate Social Responsibility. American Behavioral Scientist 49(7): 925-936. DOI: $10.1177 / 0002764205285172$

Campbell JL. 2007. Why would corporations behave in socially responsible ways? An institutional theory of corporate social responsibility. The Academy of Management Review 32(3): 946-967. DOI: 10.5465/AMR.2007.25275684

De Villiers C, Marques A. 2016. Corporate social responsibility, country-level predispositions, and the consequences of choosing a level of disclosures. Accounting and Business Research 46(2): 167-195. DOI: 10.1080/00014788.2015.1039476

DiMaggio PJ, Powell WW. 1983. The iron cage revisited: Institutional isomorphism and collective rationality in organizational fields. American Sociological Review 48(2): 147-160.

Fernandez-Feijoo B, Romero S, Ruiz-Blanco S. 2014. Women on Boards: Do They Affect Sustainability Reporting? Corporate Social Responsibility and Environmental Management 21(6): 351-364. DOI: 10.1002/csr.1329

Garcia-Sanchez IM, Cuadrado-Ballesteros B, Frias-Aceituno, JV. 2016. Impact of the institutional macro context on the voluntary disclosure of CSR information. Long Range Planning 49(1): 15-35. DOI: 10.1016/j.lrp.2015.02.004

García-Sánchez IM, Martínez-Ferrero J. 2017. Independent directors and CSR disclosures: The moderating effects of proprietary costs. Corporate Social Responsibility and Environmental Management 24(1), 28-43. DOI: 10.1002/csr.1389

Hedberg CJ, von Malmborg F. 2003. The Global Reporting Initiative and corporate sustainability reporting in Swedish companies. Corporate Social Responsibility and Environmental Management 10(3): 153-164. DOI: 10.1002/csr.38

Herda DN, Taylor ME, Winterbotham G. 2014. The effect of country-level investor protection on the voluntary assurance of sustainability reports. Journal of International Financial Management \& Accounting 25(2): 209-236. DOI: 10.1111/jifm.12018

Ho FN, Wang HMD, Vitell SJ. 2012. A Global analysis of corporate social performance: The effects of cultural and geographic environments. Journal of Business Ethics 107(4): 423-433. DOI: 10.1007/s10551-011-1047-y

Hofstede G. 1980. Cultures Consequences: International Differences in Work-Related Values. Sage Publications: Beverly Hills, CA.

House RJ, Hanges PJ, Javidan M, Dorfman PW, Gupta V. 2004. Culture, leadership and Organisations: The GLOBE study of 62 societies. Sage Publications: Thousand Oaks, CA.

Hur, MM, Kim H, Jang JH. 2016. The role of gender differences in the impact of CSR perceptions on corporate marketing outcomes. Corporate Social Responsibility and Environmental Management 23(6): 345-357. DOI: 10.1002/csr.1380 
Hyde JS. 2014. Gender Similarities and Differences. Annual Review of Psychology 65: 373-398. DOI: 10.1146/annurev-psych-010213-115057

Jones RJ, Reilly TM, Cox MZ, Cole BM. 2017. Gender makes a difference: Investigating consumer purchasing behavior and attitudes toward corporate social responsibility policies. Corporate Social Responsibility and Environmental Management. Published online in Wiley Online Library. DOI: 10.1002/csr.1401

Kassinis G, Panayiotou A, Dimou A, Katsifaraki G. 2016. Gender and environmental sustainability: A longitudinal analysis. Corporate Social Responsibility and Environmental Management 23(6): 399-412. DOI: 10.1002/csr.1386

Kaufmann D, Kraay A, Zoido-Lobatón P. 1999. 'Governance matters'. World Bank Policy Research Working Paper No. 2196

Kolk A, Perego P. 2010. Determinants of the adoption of sustainability assurance statements: An international investigation. Business Strategy and the Environment 19(3): 182-198. DOI: 10.1002/bse.643

Konrad AM, Corrigall E, Lieb P, Ritchie JE. 2000. Sex differences in job attribute preferences among managers and business students. Group \& Organization Management 25(2):108-131. DOI: 10.1177/1059601100252002

Landry EE, Bernardi RA, Bosco SM. 2014. Recognition for sustained corporate social responsibility: Female directors make a difference. Corporate Social Responsibility and Environmental Management 23(1): 27-36. DOI: 10.1002/csr.1358

Legendre S, Coderre F. 2013. Determinants of GRI G3 application levels: the case of the fortune global 500. Corporate Social Responsibility and Environmental Management 20(3): 182-192. DOI: 10.1002/csr.1285

Li S, Fetscherin M, Alon I, Lattemann C, Yeh K. 2010. Corporate social responsibility in emerging markets. Management International Review 50(5): 635-654. DOI: $10.1007 / \mathrm{s} 11575-010-0049-9$

Lock I, Seele P. 2015. Analyzing sector-specific CSR reporting: Social and environmental disclosure to investors in the chemicals and banking and insurance industry. Corporate Social Responsibility and Environmental Management 22(2): 113-128. DOI: $10.1002 / \mathrm{csr} .1338$

Marques PA, Azevedo-Pereira J. 2009. Ethical ideology and ethical judgments in the Portuguese accounting profession. Journal of Business Ethics 86(2): 227-242. DOI: 10.1007/s10551-008-9845-6

Martínez-Ferrero J, Ruiz-Cano D, García-Sánchez IM. 2016. The causal link between sustainable disclosure and information asymmetry: The moderating role of the stakeholder protection context. Corporate Social Responsibility and Environmental Management 23(5): 319-332. DOI: 10.1002/csr.1379

Matten D, Moon J. 2008. 'Implicit' and 'explicit' CSR: A conceptual framework for a comparative understanding of corporate social responsibility. Academy of Management Review 33(2): 404-424. DOI: 10.5465/AMR.2008.31193458

Moroney R, Windsor C, Aw YT. 2012. Evidence of assurance enhancing the quality of voluntary environmental disclosures: an empirical analysis. Accounting \& Finance 52(3): 903-939. DOI: 10.1111/j.1467-629X.2011.00413.x

North DC. 1990. Institutions, institutional change and economic performance. Cambridge University Press: New York.

Orij R. 2010. Corporate social disclosures in the context of national cultures and stakeholder theory. Accounting, Auditing \& Accountability Journal 23(7): 868-889. DOI: $10.1108 / 09513571011080162$

Ortas E, Gallego-Alvarez I, Álvarez-Etxeberria I. 2015. Financial factors influencing the quality of corporate social responsibility and environmental management disclosure: 
A quantile regression approach Corporate Social Responsibility and Environmental Management 22(6): 362-380. DOI: 10.1002/csr.1351

Ringov D, Zollo M. 2007. The impact of national culture on corporate social performance. Corporate Governance: The International Journal of Business in Society 7(4): 476485. DOI: $10.1108 / 14720700710820551$

Ruegger D, King EW. 1992. A study of the effect of age and gender upon student business ethics. Journal of Business Ethics 11(3): 179-186. DOI: 10.1007/BF00871965

Scholtens B, Sievänen R. 2013. Drivers of socially responsible investing: A case study of four Nordic countries. Journal of Business Ethics 115(3): 605-616. DOI: 10.1007/s10551-012-1410-7

Setó-Pamies D. 2015. The relationship between women directors and corporate social responsibility. Corporate Social Responsibility and Environmental Management 22(6): 334-345. DOI: 10.1002/csr.1349

Sierra L, Zorio A, García-Benau MA. 2013. Sustainable Development and Assurance of Corporate Social Responsibility Reports Published by Ibex-35 Companies. Corporate Social Responsibility and Environmental Management 20(6): 359-370. DOI: $10.1002 /$ csr. 1303

Sikula A, Costa AD. 1994. Are women more ethical than men? Journal of Business Ethics 13(11): 859-871. DOI: 10.1007/BF00871700

Simnett R, Vanstraelen A, Chua WF. 2009. Assurance on sustainability reports: An international comparison. The Accounting Review 84(3): 937-967. DOI: 10.2308/accr.2009.84.3.937

Thanetsunthorn N. 2015. The impact of national culture on corporate social responsibility: evidence from cross-regional comparison. Asian Journal of Business Ethics 4(1): 35-56. DOI: $10.1007 / \mathrm{s} 13520-015-0042-2$

Toppinen A, Li N, Tuppura A, Xiong Y. 2012. Corporate responsibility and strategic groups in the forest-based industry: exploratory analysis based on based on the Global Reporting Initiative (GRI) framework. Corporate Social Responsibility and Environmental Management 19 (4), 191-205. DOI: 10.1002/csr.256

Van der Laan Smith J, Adhikari A, Tondkar RH. 2005. Exploring differences in social disclosures internationally: A stakeholder perspective. Journal of Accounting and Public Policy 24(2): 123-151. DOI: 10.1016/j.jaccpubpol.2004.12.007

Wang LC, Calvano L. 2015. Is business ethics education effective? An analysis of gender, personal ethical perspectives, and moral judgment. Journal of Business Ethics 126(4): 591-602. DOI: 10.1007/s10551-013-1973-y

Williams SM. 1999. Voluntary environmental and social accounting disclosure practices in the Asia-Pacific region: An international empirical test of political economy theory. The International Journal of Accounting 34(2): 209-238. DOI: 10.1016/S0020-7063(99)00006-0 


\begin{tabular}{|c|c|c|c|c|c|}
\hline Country & $\begin{array}{l}\text { No. of } \\
\text { Reports }\end{array}$ & $\begin{array}{r}\text { Percent of } \\
\text { total, } \%\end{array}$ & $\begin{array}{l}\text { Reports per } \\
\text { Million of } \\
\text { Inhabitants }\end{array}$ & $\begin{array}{r}\text { Mean of } \\
\text { Application } \\
\text { Level }\end{array}$ & $\begin{array}{r}\text { Mean of } \\
\text { Assurance, } \%\end{array}$ \\
\hline Australia & 457 & 5.90 & 3.465 & 3.807 & 38.00 \\
\hline Austria & 182 & 2.35 & 3.622 & 4.441 & 60.94 \\
\hline Belgium & 118 & 1.52 & 1.797 & 2.662 & 20.63 \\
\hline Canada & 319 & 4.12 & 1.561 & 3.387 & 20.79 \\
\hline Chile & 214 & 2.76 & 2.098 & 4.341 & 22.92 \\
\hline Czech Republic & 11 & 0.14 & 0.127 & 4.250 & 58.33 \\
\hline Denmark & 72 & 0.93 & 2.160 & 3.639 & 44.19 \\
\hline Finland & 183 & 2.36 & 5.675 & 2.627 & 24.34 \\
\hline France & 165 & 2.13 & 0.420 & 2.557 & 21.80 \\
\hline Germany & 370 & 4.78 & 0.757 & 4.184 & 36.12 \\
\hline Greece & 138 & 1.78 & 2.050 & 3.766 & 32.57 \\
\hline Hungary & 125 & 1.61 & 2.085 & 3.533 & 30.98 \\
\hline Ireland & 19 & 0.25 & 0.696 & 5.331 & 71.11 \\
\hline Israel & 68 & 0.88 & 1.419 & 3.719 & 14.51 \\
\hline Italy & 312 & 4.03 & 0.870 & 5.056 & 61.24 \\
\hline Japan & 410 & 5.30 & 0.534 & 2.104 & 11.13 \\
\hline Korea (South) & 496 & 6.41 & 1.672 & 4.490 & 51.38 \\
\hline Luxembourg & 21 & 0.27 & 6.840 & 3.564 & 57.22 \\
\hline Mexico & 160 & 2.07 & 0.222 & 4.213 & 49.21 \\
\hline Netherlands & 380 & 4.91 & 3.811 & 3.847 & 41.08 \\
\hline New Zealand & 65 & 0.84 & 2.767 & 2.772 & 28.49 \\
\hline Norway & 89 & 1.15 & 2.794 & 3.202 & 30.47 \\
\hline Poland & 48 & 0.62 & 0.210 & 2.674 & 13.22 \\
\hline Portugal & 205 & 2.65 & 3.111 & 4.470 & 49.22 \\
\hline Spain & 957 & 12.36 & 3.439 & 5.364 & 56.65 \\
\hline Sweden & 428 & 5.53 & 7.580 & 3.095 & 40.79 \\
\hline Switzerland & 277 & 3.58 & 5.881 & 3.702 & 28.23 \\
\hline Turkey & 67 & 0.87 & 0.153 & 2.036 & 6.85 \\
\hline United Kingdom & 357 & 4.61 & 0.945 & 3.795 & 41.77 \\
\hline United States & 1,027 & 13.27 & 0.552 & 2.940 & 12.04 \\
\hline Total & 7,740 & 100.00 & 2.310 & 3.652 & 35.87 \\
\hline
\end{tabular}

Table 1. GRI reports for the period 2007-2012 in 30 OECD countries 


\begin{tabular}{|c|c|c|c|c|c|c|c|c|c|c|c|c|}
\hline Country & 1 & 2 & 3 & 4 & 5 & 6 & 7 & 8 & 9 & 10 & 11 & $\mathrm{~T}$ \\
\hline Australia & 15 & 84 & 28 & 38 & 16 & 6 & 79 & 15 & 62 & 51 & 63 & 457 \\
\hline Austria & 15 & 23 & 26 & 12 & 7 & 16 & 36 & 6 & 13 & 12 & 16 & 182 \\
\hline Belgium & 0 & 19 & 4 & 17 & 9 & 5 & 14 & 8 & 2 & 25 & 15 & 118 \\
\hline Canada & 40 & 82 & 17 & 17 & 7 & 0 & 74 & 21 & 30 & 15 & 16 & 319 \\
\hline Chile & 15 & 74 & 10 & 24 & 14 & 2 & 12 & 11 & 15 & 14 & 23 & 214 \\
\hline Czech Republic & 0 & 5 & 0 & 0 & 0 & 0 & 3 & 0 & 0 & 2 & 1 & 11 \\
\hline Denmark & 0 & 4 & 20 & 6 & 8 & 9 & 12 & 0 & 6 & 0 & 7 & 72 \\
\hline Finland & 14 & 47 & 21 & 25 & 17 & 9 & 14 & 9 & 8 & 3 & 16 & 183 \\
\hline France & 14 & 13 & 20 & 27 & 23 & 12 & 18 & 13 & 12 & 5 & 8 & 165 \\
\hline Germany & 19 & 43 & 40 & 67 & 37 & 9 & 68 & 16 & 30 & 15 & 26 & 370 \\
\hline Greece & 14 & 26 & 17 & 6 & 10 & 4 & 20 & 20 & 2 & 5 & 14 & 138 \\
\hline Hungary & 10 & 3 & 10 & 11 & 13 & 7 & 25 & 16 & 16 & 3 & 11 & 125 \\
\hline Ireland & 0 & 10 & 0 & 2 & 0 & 0 & 4 & 0 & 0 & 0 & 3 & 19 \\
\hline Israel & 0 & 12 & 3 & 5 & 8 & 3 & 17 & 11 & 2 & 1 & 6 & 68 \\
\hline Italy & 33 & 43 & 48 & 28 & 26 & 3 & 42 & 14 & 51 & 5 & 19 & 312 \\
\hline Japan & 36 & 52 & 65 & 48 & 25 & 9 & 51 & 75 & 0 & 3 & 46 & 410 \\
\hline Korea (South) & 51 & 47 & 95 & 47 & 30 & 13 & 55 & 25 & 33 & 49 & 51 & 496 \\
\hline Luxembourg & 0 & 6 & 5 & 0 & 3 & 0 & 7 & 0 & 0 & 0 & 0 & 21 \\
\hline Mexico & 15 & 30 & 22 & 17 & 24 & 13 & 20 & 5 & 0 & 6 & 8 & 160 \\
\hline Netherlands & 10 & 30 & 41 & 45 & 49 & 22 & 79 & 25 & 21 & 28 & 30 & 380 \\
\hline New Zealand & 8 & 0 & 7 & 12 & 6 & 0 & 1 & 3 & 17 & 5 & 6 & 65 \\
\hline Norway & 13 & 11 & 21 & 13 & 10 & 1 & 10 & 1 & 4 & 0 & 5 & 89 \\
\hline Poland & 13 & 3 & 9 & 1 & 7 & 0 & 3 & 1 & 9 & 0 & 2 & 48 \\
\hline Portugal & 7 & 16 & 54 & 17 & 8 & 8 & 33 & 14 & 22 & 21 & 5 & 205 \\
\hline Spain & 43 & 46 & 115 & 123 & 51 & 61 & 190 & 34 & 64 & 129 & 101 & 957 \\
\hline Sweden & 3 & 54 & 58 & 68 & 25 & 12 & 87 & 23 & 5 & 24 & 69 & 428 \\
\hline Switzerland & 6 & 38 & 31 & 24 & 25 & 19 & 62 & 16 & 29 & 5 & 21 & 277 \\
\hline Turkey & 5 & 4 & 12 & 7 & 15 & 8 & 5 & 4 & 2 & 4 & 1 & 67 \\
\hline United Kingdom & 29 & 65 & 37 & 54 & 39 & 12 & 66 & 17 & 7 & 18 & 13 & 357 \\
\hline United States & 69 & 136 & 100 & 110 & 145 & 77 & 90 & 107 & 95 & 34 & 64 & 1,027 \\
\hline Total & 497 & 1,026 & 936 & 871 & 658 & 340 & 1,197 & 510 & 557 & 482 & 666 & 7,740 \\
\hline Percent & 6.4 & 13.3 & 12.1 & 11.3 & 8.5 & 4.4 & 15.5 & 6.6 & 7.2 & 6.2 & 8.6 & 100 \\
\hline
\end{tabular}

Table 2. Distribution of GRI reports by country and type of industry

1=Energy; $2=$ Materials; $3=$ Industrials; $4=$ Consumer Discretionary; $5=$ Consumer Staples; $6=$ Health Care; 7=Financials; $8=$ Information Technology \&Telecommunication; 9=Utilities; 10=Non Profit Services, Public Agency \& Universities; 11=Other; T=Total. 


\begin{tabular}{|c|c|c|c|c|c|c|c|c|c|c|c|c|c|c|}
\hline \multirow[b]{2}{*}{ Variable } & \multirow[b]{2}{*}{ Mean } & \multirow[b]{2}{*}{$\begin{array}{l}\text { Std. } \\
\text { Dev. }\end{array}$} & \multirow[b]{2}{*}{ Min } & \multirow[b]{2}{*}{ Max } & \multicolumn{10}{|c|}{ Correlation Matrix } \\
\hline & & & & & 1 & 2 & 3 & 4 & 5 & 6 & 7 & 8 & 9 & 10 \\
\hline 1. NumGRI & 2.310 & 2.276 & 0.014 & 12.711 & 1.000 & & & & & & & & & \\
\hline 2. LevelGRI & 3.652 & 1.132 & 1.000 & 7.000 & 0.075 & 1.000 & & & & & & & & \\
\hline 3. AssurGRI & 0.359 & 0.223 & 0.000 & 1.000 & $0.178^{* *}$ & $0.829^{* * *}$ & 1.000 & & & & & & & \\
\hline 4. SeatsFemale & 25.162 & 10.227 & 7.900 & 47.000 & $0.465^{* * *}$ & 0.012 & $0.139^{*}$ & 1.000 & & & & & & \\
\hline 5. LaborFemale & 51.837 & 7.954 & 23.600 & 62.800 & $0.355^{* * *}$ & 0.029 & 0.061 & $0.556^{* * *}$ & 1.000 & & & & & \\
\hline 6. Masculinity & 51.000 & 22.311 & 5.000 & 95.000 & $-0.334^{* * *}$ & 0.036 & -0.001 & $-0.582^{* * *}$ & $-0.311^{* * * *}$ & 1.000 & & & & \\
\hline 7. LgGDPPC & 10.267 & 0.631 & 8.891 & 11.364 & $0.392^{* * *}$ & -0.005 & $0.163^{* *}$ & $0.455^{* * *}$ & $0.652^{* * *}$ & $-0.180^{* *}$ & 1.000 & & & \\
\hline 8. Industry 1 & 0.285 & 0.153 & $\begin{array}{l}0.071 \\
0.000\end{array}$ & 1.000 & $-0.163^{* *}$ & $0.184^{* *}$ & 0.088 & -0.082 & $0.140^{*}$ & 0.026 & $-0.149^{* *}$ & 1.000 & & \\
\hline 9. Industry 2 & 0.139 & 0.117 & 0.000 & 1.000 & 0.111 & $0.263^{* * *}$ & $0.347^{* * *}$ & -0.019 & 0.032 & 0.096 & $0.269^{* * *}$ & $-0.296^{* * * *}$ & 1.000 & \\
\hline 10. Legal & 0.233 & 0.424 & 0.000 & 1.000 & $-0.152^{* *}$ & 0.010 & -0.087 & $-0.191^{* *}$ & $0.387^{* * * *}$ & $0.202^{* * * *}$ & $0.191^{* *}$ & 0.077 & -0.027 & 1.000 \\
\hline
\end{tabular}

Table 3. Descriptive statistics and correlation matrix

Number of observations: 180 . Statistical significance: ${ }^{* * *}<0.01,{ }^{* *}<0.05,{ }^{*}<0.10$. 


\begin{tabular}{|c|c|c|c|c|c|c|}
\hline \multirow[b]{2}{*}{ Independent Variables } & \multicolumn{3}{|c|}{ FGLS } & \multicolumn{3}{|c|}{ PCSE } \\
\hline & (1) & (2) & (3) & (1) & (2) & (3) \\
\hline SeatsFemale & $\begin{array}{c}0.061^{* * *} \\
(0.012)\end{array}$ & & & $\begin{array}{l}0.068^{* *} \\
(0.027)\end{array}$ & & \\
\hline LaborFemale & & $\begin{array}{c}0.094^{* * *} \\
(0.016)\end{array}$ & & & $\begin{array}{c}0.115^{* * *} \\
(0.035)\end{array}$ & \\
\hline Masculinity & & & $\begin{array}{c}-0.028^{* * *} \\
(0.006)\end{array}$ & & & $\begin{array}{c}-0.025^{\text {*** }} \\
(0.012)\end{array}$ \\
\hline LgGDPPC & $\begin{array}{c}0.760^{* * *} \\
(0.198)\end{array}$ & $\begin{array}{c}0.637^{* * *} \\
(0.1743)\end{array}$ & $\begin{array}{c}0.882^{* * *} \\
(1.741)\end{array}$ & $\begin{array}{c}1.182^{* * *} \\
(0.389)\end{array}$ & $\begin{array}{l}0.848^{* *} \\
(0.423)\end{array}$ & $\begin{array}{c}1.537^{\text {** }} \\
(0.342)\end{array}$ \\
\hline Industry1 & $\begin{array}{r}-0.255 \\
(0.308)\end{array}$ & $\begin{array}{l}-0.761^{*} \\
(0.438)\end{array}$ & $\begin{array}{r}-0.254 \\
(0.289)\end{array}$ & $\begin{array}{l}-0.952^{*} \\
(0.552)\end{array}$ & $\begin{array}{r}-1.448^{* *} \\
(0.663)\end{array}$ & $\begin{array}{l}-1.011^{*} \\
(0.543)\end{array}$ \\
\hline Industry 2 & $\begin{array}{r}-0.330 \\
(0.523)\end{array}$ & $\begin{array}{r}-0.371 \\
(0.614)\end{array}$ & $\begin{array}{r}0.064 \\
(0.510)\end{array}$ & $\begin{array}{r}-0.755 \\
(1.308)\end{array}$ & $\begin{array}{r}-0.659 \\
(1.336)\end{array}$ & $\begin{array}{r}-0.761 \\
(1.224)\end{array}$ \\
\hline Legal & $\begin{array}{r}-0.640^{* *} \\
(0.300)\end{array}$ & $\begin{array}{c}-1.585^{* * *} \\
(0.311)\end{array}$ & $\begin{array}{l}-0.581^{*} \\
(0.324)\end{array}$ & $\begin{array}{c}-0.908^{* *} \\
(0.412)\end{array}$ & $\begin{array}{c}-1.961^{* * *} \\
(0.458)\end{array}$ & $\begin{array}{c}-1.071^{\text {** }} \\
(0.424)\end{array}$ \\
\hline Intercept & $\begin{array}{r}-7.418^{* * *} \\
(1.782)\end{array}$ & $\begin{array}{c}-9.090^{* * *} \\
(1.675)\end{array}$ & $\begin{array}{r}-5.822^{* * *} \\
(1.809)\end{array}$ & $\begin{array}{r}-11.154^{* * *} \\
(3.566)\end{array}$ & $\begin{array}{r}-11.607 \\
(3.446)\end{array}$ & $\begin{array}{r}-11.759^{\text {**** }} \\
(3.419)\end{array}$ \\
\hline Times dummies & Yes & Yes & Yes & Yes & Yes & Yes \\
\hline Wald Chi2 & $80.98^{* * *}$ & $66.70^{* * *}$ & $79.64^{* * *}$ & $92.03^{* * *}$ & $95.70^{* * *}$ & $91.13^{\text {**** }}$ \\
\hline R-squared & & & & 0.141 & 0.165 & 0.141 \\
\hline Number of observations & 180 & 180 & 180 & 180 & 180 & 180 \\
\hline Number of countries & 30 & 30 & 30 & 30 & 30 & 30 \\
\hline Times periods & 6 & 6 & 6 & 6 & 6 & 6 \\
\hline
\end{tabular}

Table 4. The impact of femininity on the number of GRI reports

Statistical significance: ${ }^{* * *}<0.01,{ }^{* *}<0.05,{ }^{*}<0.10$.

Standard errors are reported in parentheses. 


\begin{tabular}{|c|c|c|c|c|c|c|}
\hline \multirow[b]{2}{*}{ Independent Variables } & \multicolumn{3}{|c|}{ FGLS } & \multicolumn{3}{|c|}{ PCSE } \\
\hline & (1) & (2) & (3) & (1) & (2) & (3) \\
\hline SeatsFemale & $\begin{array}{r}0.009 \\
(0.008)\end{array}$ & & & $\begin{array}{r}0.000 \\
(0.013)\end{array}$ & & \\
\hline LaborFemale & & $\begin{array}{r}-0.005 \\
(0.137)\end{array}$ & & & $\begin{array}{r}-0.019 \\
(0.019)\end{array}$ & \\
\hline Masculinity & & & $\begin{array}{r}-0.002 \\
(0.002)\end{array}$ & & & $\begin{array}{r}0.001 \\
(0.004)\end{array}$ \\
\hline LgGDPPC & $\begin{array}{r}-0.136 \\
(0.119)\end{array}$ & $\begin{array}{r}-0.138 \\
(0.171)\end{array}$ & $\begin{array}{r}-0.064 \\
(0.098)\end{array}$ & $\begin{array}{r}-0.030 \\
(0.209)\end{array}$ & $\begin{array}{r}0.120 \\
(0.245)\end{array}$ & $\begin{array}{r}-0.019 \\
(0.168)\end{array}$ \\
\hline Industry1 & $\begin{array}{c}2.222^{* * *} \\
(0.417)\end{array}$ & $\begin{array}{c}2.185^{\text {*** }} \\
(0.436)\end{array}$ & $\begin{array}{c}2.185^{\text {*** }} \\
(0.417)\end{array}$ & $\begin{array}{c}2.502^{* * *} \\
(0.704)\end{array}$ & $\begin{array}{c}2.580^{* * *} \\
(0.706)\end{array}$ & $\begin{array}{c}2.505^{\text {*** }} \\
(0.702)\end{array}$ \\
\hline Industry2 & $\begin{array}{l}2.910^{* * *} \\
(0.521)\end{array}$ & $\begin{array}{c}2.787^{* * *} \\
(0.535)\end{array}$ & $\begin{array}{c}2.891^{\text {*** }} \\
(0.527)\end{array}$ & $\begin{array}{c}2.853^{* * *} \\
(0.946)\end{array}$ & $\begin{array}{c}2.807^{* * *} \\
(0.934)\end{array}$ & $\begin{array}{c}2.834^{\text {**** }} \\
(0.946)\end{array}$ \\
\hline Legal & $\begin{array}{r}-0.063 \\
(0.131)\end{array}$ & $\begin{array}{c}-0.118 \\
(0.126)\end{array}$ & $\begin{array}{r}-0.102 \\
(0.124)\end{array}$ & $\begin{array}{r}0.017 \\
(0.270)\end{array}$ & $\begin{array}{r}0.111 \\
(0.312)\end{array}$ & $\begin{array}{r}0.001 \\
(0.285)\end{array}$ \\
\hline Intercept & $\begin{array}{c}3.362^{* * *} \\
(1.152)\end{array}$ & $\begin{array}{c}2.636^{* * *} \\
(1.298)\end{array}$ & $\begin{array}{r}2.957 \\
(1.065)\end{array}$ & $\begin{array}{r}2.415 \\
(1.902)\end{array}$ & $\begin{array}{r}1.825 \\
(1.875)\end{array}$ & $\begin{array}{r}2.250 \\
(1.786)\end{array}$ \\
\hline Times dummies & Yes & Yes & Yes & Yes & Yes & Yes \\
\hline Wald Chi2 & $112.46^{* * *}$ & $98.82^{* * * *}$ & $111.12^{* * *}$ & $31.36^{* * * *}$ & $32.10^{* * *}$ & $31.50^{* * * *}$ \\
\hline R-squared & & & & 0.304 & 0.304 & 0.306 \\
\hline Number of observations & 180 & 180 & 180 & 180 & 180 & 180 \\
\hline Number of countries & 30 & 30 & 30 & 30 & 30 & 30 \\
\hline Times periods & 6 & 6 & 6 & 6 & 6 & 6 \\
\hline
\end{tabular}

Table 5. The impact of femininity on the application level of GRI reports

Statistical significance: ${ }^{* * *}<0.01,{ }^{* *}<0.05,{ }^{*}<0.10$.

Standard errors are reported in parentheses. 


\begin{tabular}{|c|c|c|c|c|c|c|}
\hline \multirow[b]{2}{*}{ Independent Variables } & \multicolumn{3}{|c|}{ FGLS } & \multicolumn{3}{|c|}{ PCSE } \\
\hline & (1) & (2) & (3) & (1) & (2) & (3) \\
\hline SeatsFemale & $\begin{array}{c}0.005^{* * *} \\
(0.002)\end{array}$ & & & $\begin{array}{r}0.002 \\
(0.002)\end{array}$ & & \\
\hline LaborFemale & & $\begin{array}{r}-0.001 \\
(0.003)\end{array}$ & & & $\begin{array}{r}-0.005 \\
(0.004)\end{array}$ & \\
\hline Masculinity & & & $\begin{array}{r}-0.000 \\
(0.000)\end{array}$ & & & $\begin{array}{r}0.000 \\
(0.001)\end{array}$ \\
\hline LgGDPPC & $\begin{array}{r}-0.023 \\
(0.032)\end{array}$ & $\begin{array}{r}0.047 \\
(0.037)\end{array}$ & $\begin{array}{r}0.034 \\
(0.025)\end{array}$ & $\begin{array}{r}0.032 \\
(0.043)\end{array}$ & $\begin{array}{r}0.083 \\
(0.053)\end{array}$ & $\begin{array}{r}0.050 \\
(0.036)\end{array}$ \\
\hline Industry1 & $\begin{array}{l}0.234^{* *} \\
(0.094)\end{array}$ & $\begin{array}{l}0.211^{\text {** }} \\
(0.986)\end{array}$ & $\begin{array}{l}0.202^{* *} \\
(0.095)\end{array}$ & $\begin{array}{c}0.413^{\text {*** }} \\
(0.152)\end{array}$ & $\begin{array}{c}0.434^{* * *} \\
(0.152)\end{array}$ & $\begin{array}{c}0.414^{\text {*** }} \\
(0.151)\end{array}$ \\
\hline Industry2 & $\begin{array}{c}0.667^{\text {*** }} \\
(0.118)\end{array}$ & $\begin{array}{c}0.608^{* * *} \\
(0.119)\end{array}$ & $\begin{array}{c}0.623^{\text {*** }} \\
(0.120)\end{array}$ & $\begin{array}{c}0.668^{* * *} \\
(0.191)\end{array}$ & $\begin{array}{c}0.645^{* * *} \\
(0.187)\end{array}$ & $\begin{array}{c}0.655^{\text {*** }} \\
(0.189)\end{array}$ \\
\hline Legal & $\begin{array}{r}-0.016 \\
(0.042)\end{array}$ & $\begin{array}{r}-0.045 \\
(0.042)\end{array}$ & $\begin{array}{r}-0.050 \\
(0.042)\end{array}$ & $\begin{array}{r}-0.044 \\
(0.058)\end{array}$ & $\begin{array}{r}-0.031 \\
(0.067)\end{array}$ & $\begin{array}{r}-0.060 \\
(0.061)\end{array}$ \\
\hline Intercept & $\begin{array}{r}0.237 \\
(0.297)\end{array}$ & $\begin{array}{r}-0.232 \\
(0.290)\end{array}$ & $\begin{array}{r}-0.174 \\
(0.271)\end{array}$ & $\begin{array}{r}-0.271 \\
(0.394)\end{array}$ & $\begin{array}{r}-0.514 \\
(0.409)\end{array}$ & $\begin{array}{r}-0.419 \\
(0.382)\end{array}$ \\
\hline Times dummies & Yes & Yes & Yes & Yes & Yes & Yes \\
\hline Wald Chi2 & $51.79^{* * *}$ & $42.44^{* * *}$ & $44.50^{* * *}$ & $27.16^{* * *}$ & $27.86^{* * *}$ & $27.61^{* * *}$ \\
\hline R-squared & & & & 0.235 & 0.241 & 0.235 \\
\hline Number of observations & 180 & 180 & 180 & 180 & 180 & 180 \\
\hline Number of countries & 30 & 30 & 30 & 30 & 30 & 30 \\
\hline Times periods & 6 & 6 & 6 & 6 & 6 & 6 \\
\hline
\end{tabular}

Table 6. The impact of femininity on the external assurance of GRI reports

Statistical significance: ${ }^{* * *}<0.01,{ }^{* *}<0.05,{ }^{*}<0.10$.

Standard errors are reported in parentheses. 